\title{
Influence of level and composition of concentrate supplements on rumen fermentation patterns of grazing dairy cows
}

A. M. van Vuuren, C. J. van der Koelen and J. Vroons-de Bruin

Institute for Livestock Feeding and Nutrition Research (IVVO), P.O. Box 160, 8200 AD Lelystad, Netherlands

Received 4 July 1985; accepted 10 July 1986

Key words: grazing, concentrates, starch, ruminal fermentation, dairy cows

\section{Abstract}

Six grazing dairy cows, fitted with rumen cannula, were supplemented with either high-starch concentrate, containing $258 \mathrm{~g}$ starch per kg dry matter (DM), or lowstarch concentrate ( $15 \mathrm{~g}$ starch per $\mathrm{kg} \mathrm{DM})$ in a latin-square arrangement of treatments. Animals received $1 \mathrm{~kg}$ of high-starch concentrate (1HS), $7 \mathrm{~kg}$ of high-starch concentrate (7HS), or $7 \mathrm{~kg}$ of low-starch concentrate (7LS) in two equal meals per day fed at $06 \mathrm{~h} 00$ and $16 \mathrm{~h} 00$. After a three-week adaptation, rumen samples were taken at 4-hour intervals in two 24 -hour periods. In the first 24 -hour period samples from the swards were taken immediately before rumen sampling.

Total sugar content of herbage increased during daytime with the highest concentration directly before sunset.

Patterns of ruminal $\mathrm{pH}$ values did not differ $(P>0.05)$ between treatments, and values were minimal at $24 \mathrm{~h} 00$. Volatile fatty acids (VFA) and ammonia peaked at 24h00. Extra high- or low-starch concentrate decreased ruminal concentrations of ammonia and branched-chain VFA (ammonia concentrations were 19, 13 and 12 $\mathrm{mmol} / \mathrm{litre}$ for treatments $1 \mathrm{HS}, 7 \mathrm{HS}$ and $7 \mathrm{LS}$ respectively). Acetate/propionate and non-glucogenic/glucogenic ratios within VFA, and percentage of milk fat tended $(P$ $>0.05)$ to be lowest for treatment $7 \mathrm{HS}$.

\section{Introduction}

In the Netherlands, fertilization of grassland for dairy production has increased from an average of 150 to more than $300 \mathrm{~kg}$ nitrogen $(\mathrm{N})$ per hectare during the last twenty years (van Dijk et al., 1983). Such fertilization reduces the period required for swards to reach the grazing stage (1700 kg organic matter (OM) per hectare). Over the past two decades grasslands have been renewed and nearly become monocultures, consisting primarily of perennial ryegrass. These factors have altered the 
botanical and chemical composition of the swards, resulting in a change in the composition of herbage consumed by grazing dairy cows (van Vuuren, 1985). Highly digestible grasses, such as Lolium perenne, at an early stage of maturity with a low proportion of stems have less lignified cell walls, a relatively high rate of digestion (Cammell et al., 1983) and probably a decreased 'structural index'.

To meet energy requirements, and to overcome variation in herbage allowance, it became common practice to supply concentrates to dairy cows during the grazing period. The surplus of nitrogen in herbage is balanced to some degree by using concentrate mixtures low in protein but rich in energy (approximately 7.0 MJ net energy $\left(E_{\mathrm{N}}\right)$ per $\mathrm{kg}$ ), mainly composed of ingredients with a high proportion of easily fermentable carbohydrates. However this greater quantity of rapidly fermentable carbohydrates together with a low proportion of 'structural fibre' may enhance the risk of decreased fibre digestion, resulting in lower feed intake and low milk fat (Keuning, 1980).

Information about rumen fermentation in grazing dairy cows is limited (van Adrichem, 1962; Beever \& Siddons, 1986). The aim of the present experiment was to study the influence of $1 \mathrm{~kg}$ versus $7 \mathrm{~kg}$ of concentrate on rumen parameters in grazing dairy cows.

However, because de Visser \& de Groot (1981) observed smaller variations in diurnal patterns of some rumen parameters of cows fed winter rations if the proportion of ingredients rich in starch in the concentrate mixture was decreased, composition of the concentrate mixture was included as a second variable.

\section{Material and methods}

\section{Animals, feed and treatments}

The experiment was carried out with six rumen-cannulated, pluriparae, DutchFriesian dairy cows, 6 to 18 weeks into lactation at the start. Animals grazed in swards at 80 to $90 \%$ Lolium perenne (Meijs, 1981) at a daily herbage allowance of $29 \mathrm{~kg}$ OM above $4 \mathrm{~cm}$ cutting height. Cows were split up into two blocks. Within each block treatments were allocated in a latin square arrangement. Treatments were: daily supplementation with either $1 \mathrm{~kg}$ of a ground and pelleted concentrate mixture, containing $258 \mathrm{~g}$ starch per $\mathrm{kg}$ dry matter (treatment $1 \mathrm{HS}$ ), $7 \mathrm{~kg}$ of this high-starch concentrate (7HS), or $7 \mathrm{~kg}$ of a mixture with a low concentration of starch $(15 \mathrm{~g} / \mathrm{kg}$ dry matter: treatment $7 \mathrm{LS})$. Table 1 presents the ingredients and their proportion in both mixtures. Concentrates were given in two equal portions at milking (06h00 and 16h00).

Grazing periods were alternately three or four days. After one week for changing over to a new diet, treatments continued for four weeks. The three-day grazing period of the fourth week was used for measurements. Due to weather conditions herbage had to be stall-fed in the first three weeks of the experiment.

Mean herbage intake was assumed to be the same as that measured with intact cows receiving the same treatments and grazing in another part of the same pasture in a grazing experiment conducted simultaneously (Meijs, 1984). Yields of OM of the swards were similar in the three measuring periods (approximately $1600 \mathrm{~kg}$ 
Table 1. Ingredients $(\mathrm{g} / \mathrm{kg})$ and chemical composition of concentrate mixtures and chemical composition of herbage. From Meijs (1984).

\begin{tabular}{|c|c|c|c|}
\hline \multirow[t]{2}{*}{ Ingredient } & \multicolumn{2}{|c|}{ Concentrate mixture } & \multirow[t]{2}{*}{ Herbage $^{1}$} \\
\hline & high-starch & low-starch & \\
\hline maize & 119 & - & \\
\hline sugar-beet pulp & 208 & 349 & \\
\hline tapioca meal & 228 & - & \\
\hline linseed expeller & 166 & 74 & \\
\hline coconut expeller & 139 & 50 & \\
\hline palm kernel expeller & - & 150 & \\
\hline soya bean hulls & - & 300 & \\
\hline cane molasses & 99 & 30 & \\
\hline tallow & 5 & 9 & \\
\hline $\mathrm{MgO}$ & 5 & 5 & \\
\hline vitamin/mineral premix & 32 & 33 & \\
\hline dry matter $(g / k g)$ & 876 & 904 & $235(51)$ \\
\hline nitrogen $\quad(\mathrm{g} / \mathrm{kg} \mathrm{DM})$ & 23 & 22 & $39 \quad(7)$ \\
\hline crude fibre (g/kg DM) & 92 & 223 & $242(14)$ \\
\hline$(\mathrm{g} / \mathrm{kg} \mathrm{DM})$ & 104 & 78 & $123(58)$ \\
\hline$(\mathrm{g} / \mathrm{kg} \mathrm{DM})$ & 258 & 15 & - \\
\hline
\end{tabular}

${ }^{1}$ Data of herbage based on 78 estimates; standard deviation in parenthesis.

$\mathrm{OM} / \mathrm{ha}$ ). Growth periods were 12, 23 and 27 days for period 1,2 and 3 respectively (Meijs, 1984).

\section{Sampling and analysis}

During the first 24-hour period of the measuring period the diurnal variation in chemical composition of herbage was studied by sampling (hand-cutting) a diagonal in the sward immediately before each rumen sampling. Grass samples were transported in a cooling box $\left(10^{\circ} \mathrm{C}\right)$. In a climate chamber, at $7{ }^{\circ} \mathrm{C}$, grass was chopped at about $5 \mathrm{~cm}$ with a paper-cutter, mixed by hand and divided into two subsamples. One subsample was stored at $4{ }^{\circ} \mathrm{C}$ for 36 hours (maximum) for determination of $\mathrm{N}$ solubility by the method of Tagari et al. (1962). The other subsample was stored at $-80^{\circ} \mathrm{C}$, freeze-dried, ground to pass a $1-\mathrm{mm}$ screen, and stored for analysis. Total sugar content was determined by extracting $5 \mathrm{~g}$ of sample in $40 \%(\mathrm{v} / \mathrm{v})$ ethanol at room temperature for 1 hour. After purification and weak hydrolysis the concentration of reducing sugars was determined with Luff-Schoorl reagent (Netherlands Normalization Institute, 1974). Other feed assays were completed as described by Tamminga (1981).

Immediately before the first and third 24-hour period 1.5 litres of a Cr-EDTA solution were introduced into the rumen at the afternoon milking (16h00). From this point rumen samples were taken every four hours $(20 \mathrm{~h} 00,24 \mathrm{~h} 00,04 \mathrm{~h} 00,08 \mathrm{~h} 00$, $12 \mathrm{~h} 00$, and 16h00). A stainless steel tube (length $50 \mathrm{~cm}$; inner diameter $40 \mathrm{~mm}$ ) 
closed at one end with a steel disc and perforated with approximately 120 holes, 2.5 $\mathrm{mm}$ in diameter, was inserted through the cannula and positioned such that the perforated end reached the liquor phase in the ventral sac of the rumen. Samples (approximately $200 \mathrm{ml}$ ) were taken by using a $100-\mathrm{ml}$ Janet syringe with a plastic tube (length $70 \mathrm{~cm}$; inner diameter $2.5 \mathrm{~mm}$ ).

The $\mathrm{pH}$ value of rumen fluid was measured immediately after sampling with a portable $\mathrm{pH}$ meter (C18, WPA Scientific Instruments). Samples were stored in melting ice and after 30 to 45 minutes aliquots of $5 \mathrm{ml}$ were taken for analysis of volatile fatty acids (VFA), DL-lactic acid and ammonia. Another aliquot of approximately $100 \mathrm{ml}$ was stored at $-20^{\circ} \mathrm{C}$ for chromium analysis as described by Tamminga et al. (1983). Analysis of VFA, DL-lactate and ammonia were completed as described by Robinson et al. (1986).

During the week of rumen sampling milk yield was measured on 5 days and samples from each milking were taken and analysed for fat and protein as described by Meijs (1981).

Average values of rumen parameters were calculated using the results of both 24hour periods for each time of sampling for each animal for each period. Mean $\mathrm{pH}$ values were calculated as the negative logarithm of the average hydrogen concentration. Average values were used for comparing patterns of rumen fermentation for different treatments.

Daily means of rumen parameters, and milk production for each animal for each period were subjected to analysis of variance techniques from the statistical package GENSTAT (Alvey et al., 1982) with the model:

$$
Y_{i j k}=\mu+C_{i}+P_{j}+T_{k}+\varepsilon_{i j k}
$$

where $\mu$ is the mean, $Y_{i j k}$ is the estimate of the observation in cow $i\left(C_{i}\right)$, in period $j$ $\left(P_{j}\right)$ for treatment $k\left(T_{k}\right)$, and $\varepsilon_{i j k}$ is the residual term of that observation.

\section{Results}

\section{Herbage composition}

Average concentrations ( \pm standard deviation) of DM in period I, II, and III were respectively $203 \pm 4.1,239 \pm 8.4$, and $190 \pm 13.1 \mathrm{~g} / \mathrm{kg}$. Average concentrations of total sugars in these periods were respectively $149 \pm 6.5,160 \pm 5.2$, and $101 \pm 5.1$ $\mathrm{g} / \mathrm{kg} \mathrm{DM}$, and average concentrations of nitrogen $38.2 \pm 0.98,32.3 \pm 0.31$, and $42.9 \pm 0.47 \mathrm{~g} / \mathrm{kg} \mathrm{DM}$.

Concentration of total sugars in herbage increased during daytime, reached highest values at $20 \mathrm{~h} 00$ and decreased during the night (Fig. 1). Concentrations of total sugars and $\mathrm{N}$ differed significantly between periods $(P<0.001)$. Diurnal variation in $\mathrm{N}$ content was smaller than in sugar content.

The soluble $\mathrm{N}$ fraction was 0.16 in the first period. This was significantly $(P<$ 0.001 ) lower than for the last two periods, when the soluble $\mathrm{N}$ fraction was 0.24 . Apart from a peak at $04 \mathrm{~h} 00$ a distinct diurnal pattern in $\mathrm{N}$ solubility could not be detected. 

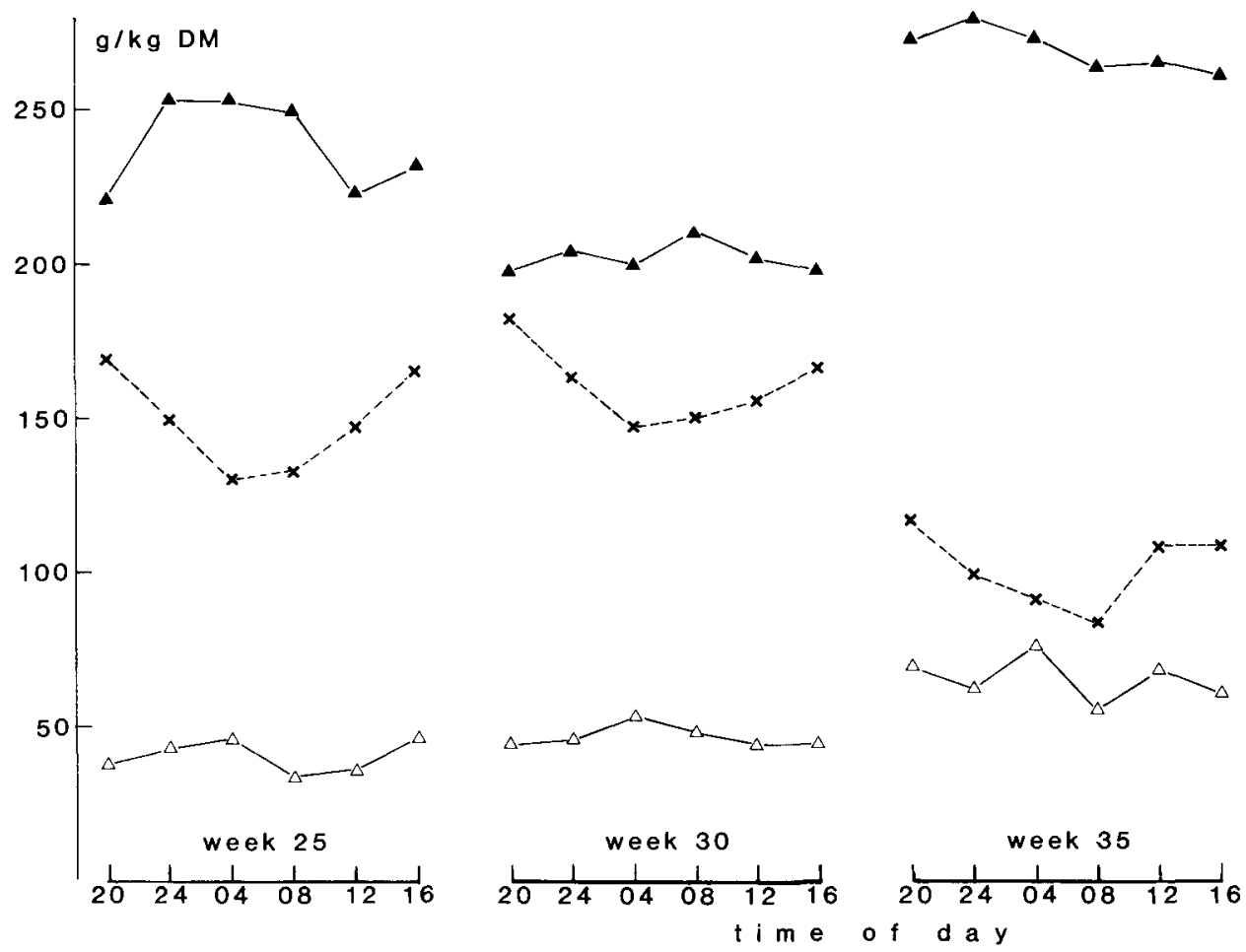

Fig. 1. Daily variation in concentrations of crude protein $(\Delta)$, soluble crude protein $(\Delta)$, and total sugars (X) in herbage, sampled in period I (week 25), period II (week 30) and in period III (week 35).

\section{Rumen parameters and milk production}

Daily patterns of ruminal $\mathrm{pH}$ values and concentrations of total VFA, and ammonia are in Fig. 2.

Treatments did not significantly affect ruminal $\mathrm{pH}$ values, except for the $08 \mathrm{~h} 00$ samples $(P<0.05)$. At that time $\mathrm{pH}$ values were inversely related to the intake of easily fermentable carbohydrates. Lowest $\mathrm{pH}$ values were at $24 \mathrm{~h} 00$, when measurements varied between 5.2 and 6.2. The diurnal variation of total VFA was the inverse of the $\mathrm{pH}$ pattern, with maximum concentrations at $24 \mathrm{~h} 00$. Concentrations of total VFA were not affected by treatments $(P>0.05)$. Ammonia concentrations peaked at $24 \mathrm{~h} 00$. Ammonia concentrations were highest on $1 \mathrm{HS}$, but varied considerably among periods: average ruminal ammonia concentrations were 11,13 and 21 $\mathrm{mmol} / \mathrm{l}$ in the three consecutive experimental periods. Therefore the concentration of ammonia was significantly higher $(P<0.05)$ for treatment $1 \mathrm{HS}$ only at $16 \mathrm{~h} 00$. Proportions of the iso-acids (iso-butyrate, and 2-methyl- and 3-methyl-butyrate) followed patterns of ammonia.

Table 2 presents daily means of rumen parameters and milk production. Average 

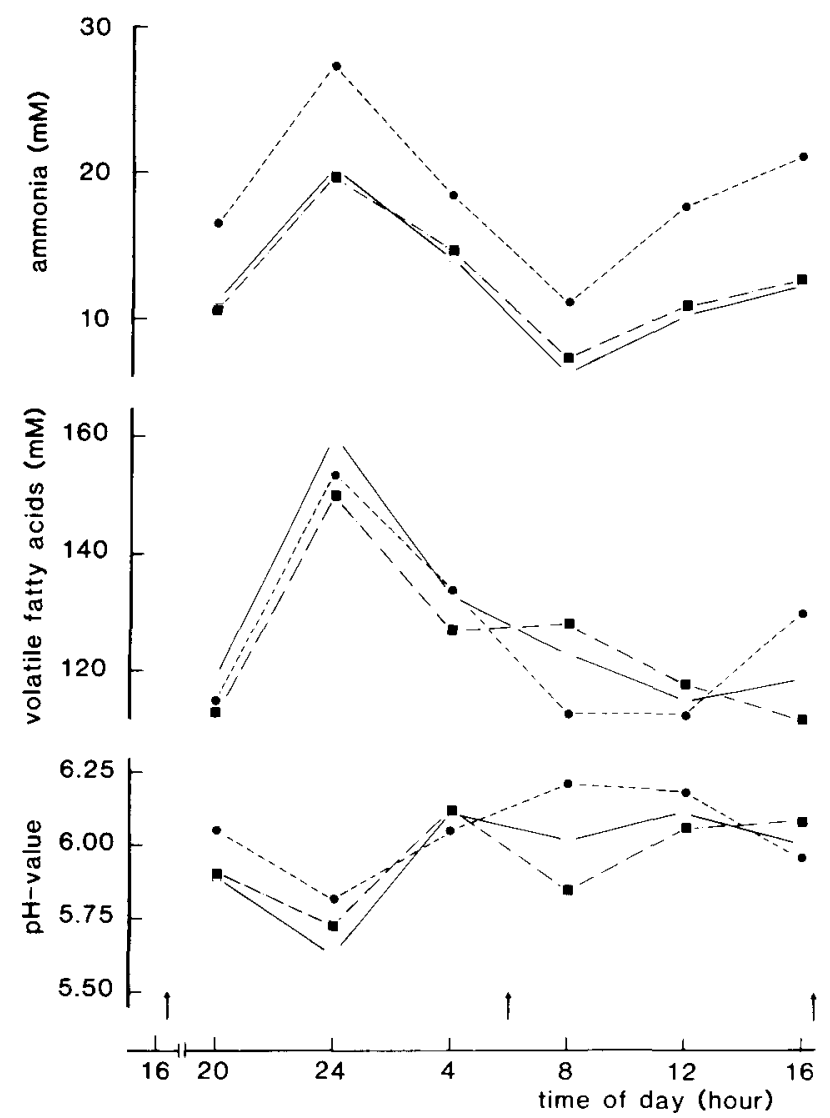

Fig. 2. Pattern of $\mathrm{pH}$ value, and concentrations of volatile fatty acids and ammonia in rumen fluid of grazing dairy cows, daily supplemented with $1 \mathrm{~kg}(\bullet)$, and $7 \mathrm{~kg}(\boldsymbol{\square})$ of a high-starch concentrate, and 7 $\mathrm{kg}(\square)$ of a low-starch concentrate. Arrows indicate time of feeding concentrate.

production of $4 \%$ fat corrected milk (FCM) in the three consecutive measuring periods was $24.1,17.2$, and $16.3 \mathrm{~kg} /$ day respectively.

When feeding $1 \mathrm{~kg}$ of concentrate the proportion of iso-acids and concentration of ammonia were higher than when feeding $7 \mathrm{~kg}$ of concentrate $(P<0.05)$. Other rumen parameters were not significantly influenced by the amount of concentrate.

Composition of the concentrate affected the outflow rate of rumen fluid $(P<$ 0.05 ), being higher on the low-starch concentrate. Other rumen parameters and milk composition were not affected by composition of concentrate $(P>0.05)$.

\section{Discussion}

\section{Herbage composition}

Diurnal variations in total sugar content were similar to observations reported by 
Table 2. The effect of amount and composition of concentrate on rumen fermentation and milk production of grazing dairy cows. Per treatment $n=6$. Values in one row with different superscript vary significantly $(P<0.05)$.

\begin{tabular}{|c|c|c|c|c|}
\hline \multirow[b]{3}{*}{ Intake $(\mathrm{kg} \mathrm{OM} / \text { day })^{1}$ : herbage } & \multicolumn{3}{|c|}{ Treatment } & \multirow{4}{*}{$\begin{array}{l}\text { Least } \\
\text { significant } \\
\text { difference }\end{array}$} \\
\hline & $1 \mathrm{HS}$ & $7 \mathrm{HS}$ & $7 \mathrm{LS}$ & \\
\hline & $\rightarrow \quad 13.4$ & 11.3 & 12.8 & \\
\hline concentrate & $\rightarrow \quad 0.8$ & 5.4 & 5.2 & \\
\hline \multicolumn{5}{|l|}{ Rumen fermentation ${ }^{2}$} \\
\hline pH value & 6.0 & 5.9 & 5.9 & 0.13 \\
\hline total VFA $(\mathrm{mmol} / \mathrm{l})$ & 127 & 127 & 130 & 16.7 \\
\hline acetate/propionate & 3.2 & 2.8 & 3.2 & 0.61 \\
\hline non-glucogenic/glucogenic & 4.4 & 3.9 & 4.2 & 0.58 \\
\hline iso-VFA/total VFA $(\%)$ & $2.7^{\mathrm{a}}$ & $2.2^{\mathrm{b}}$ & $2.1^{\mathrm{b}}$ & 0.37 \\
\hline ammonia $(\mathrm{mmol} / \mathrm{l})$ & $19^{\mathrm{a}}$ & $13^{\mathrm{b}}$ & $12^{\mathrm{b}}$ & 1.7 \\
\hline DL-lactic acid (mmol/l) & 1.0 & 1.0 & 0.8 & 0.76 \\
\hline rumen fluid outflow rate $(/ \mathrm{d})$ & $5.0^{\mathrm{ab}}$ & $4.8^{\mathrm{a}}$ & $5.3^{\mathrm{b}}$ & 0.37 \\
\hline \multicolumn{5}{|l|}{ Milk production } \\
\hline yield (kg/day) & 19.3 & 20.0 & 18.9 & 3.56 \\
\hline fat content $(\mathrm{g} / \mathrm{kg})$ & 41 & 38 & 41 & 3.4 \\
\hline protein content $(\mathrm{g} / \mathrm{kg})$ & 33 & 35 & 33 & 2.3 \\
\hline
\end{tabular}

${ }^{1}$ From different cows in a grazing experiment (Meijs, 1984).

2 Based on two 24-hour periods; 6 samples per $24 \mathrm{~h}$.

Holt \& Hilst (1969) and Smith (1973). Due to photosynthesis the concentration of total sugars increases during daylight and decreases during the night. As shown by Kühbauch (1973) total sugars extracted in a $40 \%(\mathrm{v} / \mathrm{v})$ ethanol solution consist mainly of mono- and disaccharides and low-polymere fructosans. However most diurnal variation can be attributed to fluctuations in concentration of sucrose (Smith, 1973).

Total sugars are rapidly fermented by rumen microbes. If rate and extent of fermentation exceeds the absorption of produced VFA, high concentrations of VFA and low $\mathrm{pH}$ values may develop.

Daily fluctuations in total $\mathrm{N}$ existed, but were less pronounced as compared with patterns of total sugars. Towards the end of the summer period nitrogen concentrations increased, a tendency also reported by Cammell et al. (1983) and Losada et al. (1982).

$\mathrm{N}$-solubility varied slightly during the day.

\section{Rumen parameters and milk production}

Although rumen samples were taken not too frequently, the results indicate that patterns of rumen fermentation (VFA, $\mathrm{NH}_{3}, \mathrm{pH}$ value) of grazing dairy cows differ from patterns on winter rations. On winter rations patterns of rumen fermentation are mainly affected by frequency and time of feeding concentrates (Robinson et al., 1986). In our experiment the effect of feeding concentrates was less pronounced and thus amount and composition of concentrate mixtures apparently did not influ- 
ence patterns of VFA concentration and $\mathrm{pH}$ value (Fig. 2).

Concentrations of ammonia peaked at $24 \mathrm{~h} 00$, probably as a result of a considerable ingestion of herbage in early evening. Behaviour studies with a Kienzle vibrarecorder visualized a 'bulking period' at late-afternoon/early-evening, when animals grazed for three hours or longer, with minor or no resting periods (Meijs, unpublished data). We assume that this eating period, in addition to the higher DM content of the herbage at that time, results in a relatively high rate of DM consumption between $18 \mathrm{~h} 00$ and $21 \mathrm{~h} 00$, succeeding in high concentrations of fermentation products. During night-time grazing activities are scarce and concentrations of fermentation products decrease. Between $08 \mathrm{~h} 00$ and $16 \mathrm{~h} 00$ ammonia concentrations gradually raise, probably as a result of a moderate herbage intake.

The relatively high concentrations of ammonia indicate a substantial degradation of protein in the rumen, which agrees with results reported by Beever \& Siddons (1986). Concentrations of ammonia decreased when feeding $7 \mathrm{~kg}$ of concentrate irrespective of its composition. An explanation may be found in the grazing experiment where herbage intake was lower when feeding $7 \mathrm{~kg}$ of concentrate. A lower herbage intake, combined with a higher intake of concentrate not only changes the ration between digestible organic matter (DOM) and digestible crude protein (DXP), but also may result in differences in rumen-degradable crude protein (RDXP). Crude protein (XP) in herbage is highly degradably in the rumen: 75 to $85 \%$ of herbage XP disappeared in incubations in sacco (Veen, 1984; van der Tol $\&$ van Vuuren, 1986). Calculations based on incubations in sacco of concentrate ingredients ( $\mathrm{S}$. Tamminga, personal communication) showed that rate and extent of XP degradation in the rumen may have been less when feeding more concentrate, thus resulting in lower ammonia concentrations.

DOM/DXP ratio increased from 3.8 on diet $1 \mathrm{HS}$ to 4.4 when feeding $7 \mathrm{~kg}$ of concentrate. A higher DOM/DXP ratio may have been benificial for microbial growth, resulting in relatively higher incorporation of ammonia- $\mathrm{N}$ into microbial protein. Lower XP degradation and/or more efficient microbial protein synthesis may also explain the lower proportions of branched-chain iso-acids observed when feeding 7 $\mathrm{kg}$ of concentrate (Papas et al., 1984). Another result could have been a higher duodenal protein supply, possibly explaining the increase of milk protein observed in the grazing experiment (Meijs, 1984).

Concentrations of VFA peaked at $24 \mathrm{~h} 00$, an observation also reported by Mpatwa et al. (1978). The 'bulking period', the relatively high DM content of herbage eaten in early-evening, and the higher sugar concentration in the DM may have been responsible for this phenomenon. Accounting for the change in DM content the difference in sugar content between morning and evening was $15 \mathrm{~g}$ per $\mathrm{kg}$ fresh herbage. This difference was rather constant, despite significant variations between periods (Fig. 1). VFA concentrations decreased during night, probably due to low herbage consumption. Between $04 \mathrm{~h} 00$ and $20 \mathrm{~h} 00$ fluctuations in VFA concentrations were small, which might indicate a moderate and gradual ingestion of herbage with a relatively lower DM content.

Low concentrations of DL-lactate suggest low production of lactate and/or adequate fermentation of lactate. However with the four hours interval of sampling 
the peaks (generally short-lasting) in the concentration of lactate (Counotte, 1981; Robinson et al., 1986) could have been overlooked.

From the amount or composition of the concentrate mixture no significant effect on $\mathrm{pH}$ values and concentrations of total VFA or lactic acid in the rumen have been observed. From data of his grazing experiment Meijs (1984) calculated average daily consumptions of $2.0,3.6$, and $2.1 \mathrm{~kg}$ of starch plus sugars for treatments $1 \mathrm{HS}$, 7HS, and 7LS respectively. The main starch component in the high-starch concentrate was tapioca. In incubations in vitro of tapioca in rumen liquor Malestein et al. (1982) observed a moderate decrease of $\mathrm{pH}$ value and a minor increase in concentration of L-lactate. On the other hand, in studies in vivo feeding wilted grass-silage de Visser \& de Groot (1981) found a negative effect on rumen fermentation when supplementing high amounts of concentrate containing $300 \mathrm{~g} / \mathrm{kg}$ tapioca. Our experiment does not confirm the latter results. However observations from the grazing experiment may explain this contradiction: Meijs (1984) observed a lower herbage intake for treatment 7HS, resulting in a decreased ingestion of neutral detergent (ND) fibre of approximately $1 \mathrm{~kg}$ per day. ND fibre of abundantly fertilized young herbage is rapidly fermentable ( $\mathrm{S}$. Tamminga, unpublished results). Therefore it seems that rate and extent of carbohydrate degradation was not extremely different among treatments, and changes in VFA concentrations and $\mathrm{pH}$ values were not apparent. Changing some ND fibre into tapioca starch could have resulted in a change in the composition of fermentation products, indicated by the tendency for a shift in acetate/propionate ratio for treatment 7HS. This is also reflected by a slightly lower milk fat content in treatment $7 \mathrm{HS}$.

Outflow rates of rumen fluid were higher than those observed by Cammell et al. (see Beever \& Siddons, 1986) in steers. In contradiction to their results our data did not show a seasonal influence on outflow rates. However a possible effect of season may have been counteracted by the influence of milk yield on the fluid outflow rate (van Vuuren, 1984). The higher outflow rate for treatment 7LS probably results from the higher intake of herbage.

\section{Conclusions}

Our study indicates that rumen fermentation in dairy cows grazing on highly fertilized, relatively young perennial ryegrass is not a steady process, and low $\mathrm{pH}$ values, and high concentrations of VFA and ammonia in rumen fluid occur, even with moderate supplementation of concentrate. As in other experiments (Beever \& Siddons, 1986) our data demonstrate a substantial excess of nitrogen in dairy cows consuming heavily fertilized, young herbage.

\section{References}

Adrichem, P. A. W. van, 1962. De invloed van het voeder op enige fermentatieprodukten in de pens van normale runderen en van acetonaemie-patiënten. Thesis, Utrecht.

Alvey, N., N. Galwey \& P. Lane, 1982. An introduction to Genstat. Academic Press, London.

Beever, D. E. \& R. C. Siddons, 1986. Digestion and metabolism in the grazing ruminant. In: L. P. Milli- 
gan, W. L. Grovum \& A. Dobson (Eds.), Control of digestion and metabolism in ruminants, p. 479497. Prentice-Hall, Englewood Cliffs.

Cammell, S. B., D. E. Beever, D. J. Thomson, A. R. Austin, H. R. Losada, R. T. Evans, M. C. Spooner \& R. A. Terry, 1983. Energy and protein digestion, supply and utilization on two contrasting forages fed to growing steers. Animal Production 36: 501.

Counotte, G. H. M., 1981. Regulation of lactate metabolism in the rumen. Thesis, Utrecht.

Dijk, H. van, D. Oostendorp, G. J. Wisselink, P. J. Liefbroer \& M. D. C. van Diepen, 1983. The statistics of cattle, sheep and horse farming in The Netherlands. Research and Advising Institute for Cattle, Sheep and Horse Husbandry, Lelystad.

Holt, D. A. \& A. R. Hilst, 1969. Daily variation in carbohydrate content of selected forage crops. Agronomy Journal 61: 239-242.

Keuning, J. A., 1980. Vetgehalte in de melk en de structuurwaarde van het rantsoen in de weideperiode. Bedrijfsontwikkeling 11: 883-888.

Kühbauch, W., 1973. Veränderungen von Kohlenhydratfraktionen in Blättern und Stengeln einiger Knaulgrassorten während des Wachstums. Landwirtschaftliche Forschung 26: 213-220.

Losada, H. R., S. B. Cammell, D. E. Beever \& A. R. Austin, 1982. The effect of forage species and stocking rate on protein supply to the duodenum of cattle. In: D. J. Thomson, D. E. Beever \& R. G. Gunn (Eds.), Forage protein in ruminant animal production, p. 144-145. Occasional Publications of the British Society of Animal Production No 6.

Malestein, A., A. Th. van't Klooster, G. H. M. Counotte \& R. A. Prins, 1982. Concentrate feeding and ruminal fermentation. 2. Influence of concentrate ingredients on $\mathrm{pH}$ and on $\mathrm{L}$-lactate concentration in incubations in vitro with rumen fluid. Netherlands Journal of Agricultural Science 30: 259-274.

Meijs, J. A. C., 1981. Herbage intake by grazing dairy cows. Agricultural Research Reports, 909. Pudoc, Wageningen.

Meijs, J. A. C., 1984. Het effekt van krachtvoerbijvoedering op de grasopname van weidende melkkoeien. Report No 161, Institute for Livestock Feeding and Nutrition Research, Lelystad.

Mpatwa, N. G., G. D. Chopping \& R. M. Murray, 1978. Diurnal variation in concentrations of rumen fermentation end-products in grazing cattle. Proceedings of the Australian Society of Animal Production 12: 147.

Netherlands Normalization Institute, 1974. Bepaling van het gehalte aan reducerende suiker, ruwe totaal suiker, saccharose en ruwe lactose. NEN 3571. Netherlands Normalization Institute, Rijswijk.

Papas, A. M., S. R. Ames, R. M. Cook, C. J. Sniffen, C.E. Polan \& L. Chase, 1984. Production response of dairy cows fed diets supplemented with ammonia salts of iso C-4 and C-5 acids. Journal of Dairy Science 67: 276-293.

Robinson, P. H., S. Tamminga \& A. M. van Vuuren, 1986. Influence of declining level of feed intake and varying proportion of starch in the concentrate on rumen fermentation in dairy cows. Livestock Production Science 15: 173-189.

Smith, D., 1973. The nonstructural carbohydrates. In: G. W. Butler \& R. W. Baily (Eds.), Chemistry and biochemistry of herbage I, p. 106-156. Academic Press, London.

Tagari, H., I. Ascarelli \& A. Bondi, 1962. The influence of heating on the nutritive value of soyabean meal for ruminants. British Journal of Nutrition 16: 237-243.

Tamminga, S., 1981. Effect of the roughage/concentrate ratio on nitrogen entering the small intestine of dairy cows. Netherlands Journal of Agricultural Science 29: 273-283.

Tamminga, S., A. M. van Vuuren, C. J. van der Koelen, H. M. Khattab \& L. G. M. van Gils, 1983. Further studies on the effect of fat supplementation of concentrates fed to lactating dairy cows. 3 . Effect on rumen fermentation and site of digestion of dietary components. Netherlands Journal of Agricultural Science 31: 249-258.

Tol, J. J. van der \& A. M. van Vuuren, 1986. De invloed van het groeistadium op de pensafbraak van stikstof en celwandbestanddelen van weidegras. 11e Studiedag Nederlandstalige Voedingsonderzoekers, p. 6-8. Departments of Animal Nutrition and Animal Physiology, Agricultural University, Wageningen.

Veen, W. A. G., 1984. Stikstof in ruwvoeders en de fermentatie in de pens. Landbouwkundig Tijdschrift 96 (12): $25-28$.

Visser, H. de \& A. A. M. de Groot, 1981. The influence of the starch and sugar content of concentrates on feed intake, rumen fluid, production and composition of milk. In: D. Giesecke, G. Dirksen \& M. 
Stangassinger (Eds.), Metabolic disorders in farm animals, p. 41-48. Institut für Physiologie, Physiologische Chemie und Ernährungsphysiologie, München.

Vuuren, A. M. van, 1984. Effect of level of hay intake, method of marker administration and stage of lactation on rate of passage through the reticulorumen. Canadian Journal of Animal Science 64 (Supplement): 80-81.

Vuuren, A. M. van, 1985. Voedingsaspecten van de grazende koe. In: Koeievoer op het bord van de dierenarts, p. 8-20. Koninklijke Nederlandse Maatschappij voor Diergeneeskunde, afdeling Overijssel, Zwolle. 